\title{
APLICATIVOS DE CLUBES DE LEITURA COMO MEDIADORES - ANÁLISE DE UMA EXPERIÊNCIA DE LEITURA
}

\section{COMPUTING APPLICATION AS A READING MEDIATOR - ANALYSIS OF A READING EXPERIENCE}

\author{
Samira Dall Agnol \\ Universidade de Caxias do Sul, UCS, Caxias do Sul, RS, Brasil \\ Douglas Ceccagno \\ Universidade de Caxias do Sul, UCS, Caxias do Sul, RS, Brasil
}

\begin{abstract}
Resumo: Pretende-se analisar comentários de leitoras da obra As alegrias da Maternidade, de Buchi Emecheta, a partir das linhas teóricas da Estética da Recepção e do Efeito Estético, a fim de perceber as relações estabelecidas entre narrativa e leitoras. A análise torna-se pertinente na medida em que verifica as impressôes registradas no aplicativo disponibilizado aos assinantes de um clube de leitura. Esse espaço virtual oferece grande intercâmbio entre leitores, além de permitir o registro da opiniáo e das relaçóes que os assinantes estabelecem tendo como ponto em comum os livros enviados mensalmente pelo clube de leitura em questão.
\end{abstract}

Palavras-Chave: Clube de Leituras; Aplicativos de Leitura; Mediação de Leitura; Recepção do Texto Literário.

Abstract: Analyse commentaries from readers of The Joys of Motherhood, from Buchi Emecheta, grounded by Reception Aesthetics and Aesthetic Effect theoretical lines, in order to comprehend the relations between narrative and readers. This analysis becomes relevant as it verifies the impressions registered in the computing application let available by the reading club focused. This virtual space offers great interchange among readers, as well as allows the register of readers' opinions and the relations and interpretations readers establish, having in common the books sent monthly by the reading club in question.

Key words: Reading club; Computing Application for Reading; Reading Mediation; Reception of Literary Text. 


\section{Introduçáo}

Uma citação de Goethe intimida. Provoca. Engana. O que ela promete é o que o leitor capta; afinal, o autor está morto, já dizia Barthes (2004). Um texto ganha vida quando é encontrado e acolhido por seus leitores, ou morre quando é abandonado por eles. $\mathrm{O}$ acolhimento vem em forma de identificação, de elogio, de suspiro. Já o abandono talvez demonstre uma das faces menos prestigiadas do ser humano. Mesmo assim, também deve ser sentido internamente pelo leitor, tanto ao renunciar a uma leitura, quanto ao sentir-se desamparado por ela.

Em outras palavras, ser leitor é uma das possibilidades de ser humano, visto que permite compreender o "outro", seja através do diálogo, da escrita, de um clube de leituras, seja nos tecnológicos dias deste século, através de algum aplicativo de smartphone. Desse modo, estudar a recepçáo de um texto contemporâneo por meio do registro virtual de um aplicativo pode ser uma tarefa comum à humanidade, certamente não à geração de Goethe, mas à geração atual de assinantes da TAG Experiências Literárias ${ }^{1}$.

Aproveitando o tipo de interação que alguns leitores têm proposto a partir de suas leituras, este artigo pretende analisar comentários de leitoras da obra As alegrias da Maternidade, de Buchi Emecheta (2017), a partir das linhas teóricas da Estética da Recepção e do Efeito Estético, a fim de perceber as relaçóes estabelecidas entre narrativa e leitoras. Se há um objetivo neste texto, há também uma pergunta a qual se quer responder e que poderia ser sintetizada da seguinte forma: De que maneira as leitoras de As Alegrias da Maternidade relacionam sua realidade à da obra, a partir de seus relatos no aplicativo da TAG Experiências Literárias?

Tal análise torna-se pertinente na medida em que verifica, à luz das teorias mencionadas, as reaçôes, as impressôes e os depoimentos registrados pelas leitoras a partir do aplicativo disponibilizado aos assinantes do clube em questão. Esse espaço virtual possibilita grande interação entre leitores ${ }^{2}$, em um formato amigável e contemporâneo, além de permitir o registro da opiniáo, da percepção e das relaçôes que os assinantes estabelecem, tendo como ponto em comum os livros enviados pela TAG Experiências Literárias em cada mês.

\footnotetext{
1"TAG Experiências Literárias" é um clube de assinatura de livros e será abordado na seção seguinte.

${ }^{2}$ É válido explicar que o clube não secciona leitores por gênero, entretanto, o fato de analisar apenas os depoimentos de leitoras é explicado na sequência.
} 
O interesse em unir elementos da Estética da Recepção a um clube de leituras surgiu pela assinatura do clube, e por perceber neste aplicativo uma espécie de laboratório para a análise da teoria proposta, especialmente as abordagens de Jauss $(1979 ; 1994)$ e Iser $(1980 ; 1999)$, as quais apontam a configuração de um leitor ideal. Verificar a possibilidade de refletir sobre as ideias de tais autores expostas e defendidas em registros atuais de impressóes de leitura tornou-se uma inquietação. Assim, decidiu-se apresentar, neste texto, em primeiro lugar, o clube mencionado; em segundo lugar, a obra escolhida para análise dos comentários, bem como alguns aspectos teóricos que proporcionarão coerência ao estudo; e, por fim, a apreciação dos textos dos leitores, registrada no aplicativo.

\section{TAG Experiências Literárias: Upgrade do Círculo do Livro}

Nas décadas de 1970-1980, no Brasil, o Círculo do Livro fez enorme sucesso, uma vez que os leitores náo possuíam as facilidades de acesso ao livro como ocorre hoje (internet, livrarias e bibliotecas, sebos, sebos virtuais, empréstimo entre leitores, entre outros meios). Assim, muitas pessoas dependiam do clube para adquirir seus materiais de leitura. Naquela época, uma editora brasileira, vinculada ao Grupo Abril e à editora alemã Bertelsmann, enviava ao associado uma revista com títulos diversos a partir dos quais o leitor escolhia os de sua preferência e aguardava receber sua leitura mensalmente, em edições exclusivas de capa dura, as quais podem ser encontradas atualmente em sebos ${ }^{3}$.

A TAG Experiências Literárias (doravante TAG) trouxe de volta o conceito de clube do livro com a intenção de não apenas oferecer livros, mas de proporcionar uma experiência de leitura. Segundo o site do clube, dentro de cada caixinha enviada mensalmente aos assinantes existe, além de livros, uma ideia: a de que as histórias tornam o mundo mais sensível e a vida mais bonita. Para os idealizadores da TAG, assusta (e muito) a perspectiva da morte do livro e, em vista disso, criaram o clube no intuito de "construir uma experiência literária saborosa e reunir todos aqueles que adoram o cheirinho de páginas impressas, vão à livraria comprar um e voltam com dez, choram por personagens e acreditam em histórias inventadas" (TAG EXPERIÊNCIAS LITERÁRIAS, s.d., s. p.). Através dos livros, "exploramos universos literários, discutimos obras, conhecemos novos autores e

${ }^{3}$ Disponível em: https://taglivros.com/como-funciona-um-clube-do-livro. Acesso em 04 jan 2019. 
brincamos com essa fonte de prazer e transformação chamada imaginação" (TAG EXPERIÊNCIAS LITERÁRIAS, s.d., s. p.) $)^{4}$.

A TAG Experiências Literárias ${ }^{5}$, com sede na capital gaúcha, surgiu em 2014 e vem ganhando adeptos por todo o Brasil, já superando a marca de 40 mil inscritos em 2018. TAG Experiências Literárias definese como "um clube de assinatura de livros que envia, todos os meses, um kit literário surpresa às casas de nossos associados" (TAG EXPERIÊNCIAS LITERÁRIAS, s.d., s. p.) $)^{6}$.

Hoje a TAG conta com duas linhas de assinatura: a TAG Curadoria e a TAG Inéditos. Na primeira linha, mensalmente, o associado tem acesso a um título indicado por um curador escolhido pela TAG. A pessoa que indica o livro deve possuir um vínculo relevante com a leitura, os livros e o universo literário, podendo ser um escritor, um tradutor, um professor de literatura, um grande leitor, entre outros convidados que, de alguma forma, influenciam essa arte. O exemplar é acompanhado de uma revista que apresenta o autor, a obra, o curador e remete a diferentes textos e outras formas artísticas (por exemplo, filmes, músicas e outros livros) que são ou foram relacionadas à obra ou ao autor e, ainda, um mimo literário (como exemplo: capas de almofadas, blocos de anotações, marca-páginas, quebracabeças literário, etc.). A edição é sempre exclusiva, de capa dura, com uma luva que a protege, e com motivos estéticos vinculados ao mote da história, provocando o leitor a ampliar sua experiência de leitura.

$\mathrm{Na}$ segunda, o assinante recebe mensalmente um título que ainda não foi publicado no Brasil, mas que já é reconhecido no exterior. Diferentemente da primeira proposta, a TAG Inéditos tem um produto mais simples: uma brochura acompanhada de um pôster ilustrado que auxilia o leitor a mergulhar na narrativa. Na linha da TAG Inéditos, os títulos "são best-sellers de leitura rápida e linguagem contemporânea, daqueles repletos de diálogos e cenas emocionantes, que fisgam o leitor desde as primeiras páginas" (TAG EXPERIÊNCIAS LITERÁRIAS, s.d., s. p.) ${ }^{7}$.

$\mathrm{Na}$ linha da TAG Curadoria, a primeira remessa de kits foi enviada em agosto de 2014 para aproximadamente 65 associados, com o livro $\mathbf{O}$ físico, de Noah Gordon (1986), recomendado pelo filósofo Mario Sergio Cortella.

${ }^{4}$ Disponível em: https://taglivros.com/proposito. Acesso em 04 jan 2019.

5Disponível em: https://taglivros.com/. Acesso em 03 jan 2019.

${ }^{6}$ Disponível em: https://www.taglivros.com/blog/surgimento-do-clube-tag/. Acesso em 03 jan 2019.

${ }^{7}$ Disponível em: https://taglivros.com/ineditos. Acesso em 04 jan 2019. 
Ao final daquele ano, o clube ainda não havia alcançado uma centena de associados. Segundo os criadores do projeto, "dúvidas começaram a surgir, e abriram espaço para insegurança: talvez o brasileiro não leia, talvez nossa ideia não faça sentido, talvez... desistir"? (TAG EXPERIÊNCIAS LITERÁRIAS, s.d., s. p. $)^{8}$. O ponto da virada ocorreu em julho de 2016, no aniversário de 2 anos do clube, quando alcançou a marca de dez mil associados e, desse momento em diante, só fez crescer.

Já tendo os caminhos abertos pela primeira modalidade, a TAG Inéditos, iniciada em março de 2018, atende a uma fatia de leitores que não se sentia confiante em ler textos mais densos, ou náo se identificava com esse estilo. Também por ser financeiramente mais acessível, essa categoria permite que outros leitores se filiem ao clube. O primeiro título enviado nesse formato foi A Boa Filha, de Karin Slaughter (2018). Como síntese, a narrativa foca em dinâmicas e traumas familiares, apesar de ter no centro de seu enredo casos policiais. Tais acontecimentos e seus desdobramentos tornam o livro ainda mais interessante e, apesar de suas 476 páginas, lê-se em um instante, pelo dinamismo das açóes e pela linguagem acessível ${ }^{9}$.

Em 2018, o número de associados chegou a 40 mil o que, sem dúvida, é um grande marco na história da leitura do Brasil. Além da experiência que envolve a obra quando o leitor a recebe, ele também pode contar com aplicativos para smartphones, através dos quais os assinantes podem postar, comentar e trocar experiências sobre as leituras enviadas pela TAG ou ainda, em um espaço dedicado, sobre outros títulos.

\section{As Alegrias da Maternidade: A Obra}

A seleção de As Alegrias da Maternidade, de Buch Emecheta (2017), para esta análise ocorreu por diferentes razóes. Um dos motivos foi pelo romance ter sido escrito por uma mulher, contribuindo de alguma forma, para a discussão - além de atual - também proposta durante a disciplina cursada sobre Literatura Feminina. Outra questão que chamou a atenção foi a de ele ter sido o livro mais bem avaliado na história da $\mathrm{TAG}^{10}$, atingindo

${ }^{8}$ Disponível em: https://www.taglivros.com/blog/surgimento-do-clube-tag/. Acesso em 03 jan 2019.

${ }^{9}$ Disponível em: https://www.estantedelivros.com/2018/01/opiniao-a-boa-filha-karinslaughter.html. Acesso em 04 jan 2019.

${ }^{10} \mathrm{~A}$ autora do artigo é assinante da TAG Experiências Literárias - TAG Curadoria - desde março de 2016, e da TAG Inéditos desde março de 2018, por isso tem acesso aos textos 
a nota 4,8 (sendo 5,0 a nota máxima) na opinião dos leitores. Também, a possibilidade de, através do aplicativo TAG Curadoria, os leitores registrarem seus depoimentos e impressóes depois de lerem o livro, fez com que possibilitasse uma tentativa de aplicação de alguns dos conceitos relativos à Estética da Recepção em um texto atual lido por leitores contemporâneos.

A autora de As Alegrias da Maternidade, Buchi Emecheta ${ }^{11}$, nasceu em 1944, em Lagos, na Nigéria. Sua paixão, enquanto criança, era ouvir os mais velhos contando histórias, em especial sua tia, a quem chamava de Grande Mãe. Seu irmão, privilegiado por ser menino, fora para a escola, enquanto Emecheta ficava em casa até ter seus insistentes pedidos atendidos e ser matriculada em uma escola missionária para meninas, onde aprendeu línguas nativas e inglês. Muito jovem, casou-se com seu noivo, Sylvester Onwordi, mudando-se para Londres. O casal teve cinco filhos, e Emecheta vivenciou um relacionamento abusivo e violento, o que a motivou a lutar pelo divórcio, aos vinte e dois anos. Com seus cinco filhos e poucas condiçóes financeiras, trabalhou em diferentes locais, tais como a Biblioteca de Londres, além de estudar à noite. Em 1974, graduou-se em Sociologia. Sua vontade de escrever sempre esteve presente. Depois de diversas rejeiçôes, recebeu uma oportunidade como colunista no periódico inglês New Statesman, e tais crônicas formaram a base para seu primeiro livro, In the ditch (1972) e, dois anos depois, publicou Second-class citizen (1974). Além desses títulos, Buchi Emecheta escreveu e publicou The Bride Price, em 1976, e The Slave Girl, em 1977.

Em 1979, publicou The Joys of Motherhood (título original livro em análise), o qual teve, dentre seus livros, a melhor recepçáo pelo público e pela crítica da época. A primeira traduçáo para o português, realizada pela tradutora Heloisa Jahn, foi a versão produzida pela editora Dublinense, a pedido da TAG Experiências Literárias, em 2017. A história de As alegrias da Maternidade é narrada pela jovem Nnu Ego, e, como pano de fundo da narrativa, apresenta-se a Nigéria colonial da primeira metade do século $\mathrm{XX}$. Nnu Ego tem suas escolhas guiadas pelo contexto sociocultural, ou seja, espera-se que ela seja esposa e máe. Entretanto, depois de casada, percebe que não consegue gerar filhos: uma grande decepção para alguém de sua cultura. Já em seu segundo casamento, depois de muito sofrimento, ela consegue gerar e dar à luz a seu primeiro filho, o que não encerra seu martírio. Pelo contrário, o contexto de sua vida em Lagos, as dificuldades

enviados, aos materiais de apoio, aos aplicativos e demais elementos atinentes à assinatura.

${ }^{11}$ As informaçóes apresentadas nesta seção, deste trecho em diante, estão compiladas na revista da TAG Curadoria, de outubro de 2017, a qual acompanha a obra em análise. 
para sustentar sua família e as influências do colonizador inglês, além da guerra (Segunda Guerra Mundial), compóem um leque de infortúnios e obstáculos para Nnu Ego.

Buchi Emecheta explicita em sua obra a prisão em que vive a mulher nigeriana e a posiçáo de subordinação ao homem, seja ele nigeriano ou europeu. Seu marido assume a companheira e a família do irmão falecido, transformando Nnu Ego na esposa mais velha e obrigando-a a conviver com as agruras da poligamia incentivada pela cultura ancestral de sua gente, além de lidar com a situação de servilismo e subserviência, típicas funçôes femininas dentro desse contexto cultural.

A linguagem é simples e realista. A narrativa não deixa espaço para sonhos ou devaneios, apesar do dinamismo e das complexidades culturais contempladas. O processo de tomada de consciência da personagem principal ocorre apenas na dor e na aflição extremas. Por muitos motivos, o texto é instigador: pela diversidade cultural que apresenta - e pelos comparativos que podem ser traçados com outras culturas; pela percepção da mulher como peça fundamental nessa cultura, apesar de ser um objeto funcional, sem voz ou vez; pela ausência de sororidade - também entre mulheres da mesma família ou tribo; pela resiliência expressa especialmente pela personagem central, enfim, por outras tantas razóes que as leitoras elencam também em seus comentários.

\section{Teorias: $\mathrm{O}$ que afirmam os Especialistas}

As teorias que focalizam o aspecto recepcional valorizam o papel do leitor, transformando a leitura em uma forma de desvendamento do texto literário. Muitos autores se debruçam sobre esse enfoque e o que há em comum entre eles é o ponto a partir do qual estudam a literatura. Entretanto, apesar de partirem da recepçáo do texto, dependendo da abordagem, criamse vertentes diferentes dentro dessa corrente chamada Teoria da Recepção.

Por exemplo, Jauss (1994) aparece como um dos autores mais relevantes entre os que privilegiam o leitor e a leitura nos estudos literários. Jauss (1994) reivindica que se considere como princípio historiográfico o modo como um texto foi lido e avaliado por diferentes públicos na história, contemplando uma percepção do caráter artístico de um texto em razáo do efeito que gera em quem o lê. As ideias de Jauss (1994) são conhecidas sob o cunho de Estética da Recepção. 
Ilustra uma segunda linha da teoria recepcional a obra organizada por J. Tompkins, Reader-Response Criticism (1980), que conta com a colaboração de vários estudiosos, como por exemplo, Stanley Fish (1980) bem como pelo alemão, Wolfgang Iser (1999), os quais procuram dar conta dos efeitos que os textos desencadeiam em seu leitor. Segundo essa vertente, o texto somente ganha existência no momento da leitura e os 'efeitos' dessa leitura são cruciais para que se compreenda seu sentido.

Ainda, sob a rubrica de Sociologia da Leitura, e com o pioneirismo de Escarpit (1969), a quem se seguiram nomes como Roger Chartier (1996) e Pierre Bourdieu (1996), o estudo da literatura é feito através de elementos que sustentam a teia que a faz existir: os leitores, a obra e a leitura, entre outros. Também interessam todos os circuitos que envolvem o livro: a produção, a venda, a edição, as feiras do livro, etc.

Para fins deste estudo, será privilegiada a perspectiva da Estética da Recepção, com base em Jauss (1994) e Iser (1980). Essas vertentes afirmam que uma obra é passível de interpretaçóes diversas, porque é lida por públicos diferentes. A partir dessa concepção teórica, observa-se um aspecto distinto para sugerir um novo foco na literatura: a recepção do público. Entretanto, há espaço para algumas ressalvas, visto que o leitor proposto por Jauss (1994) não é nem virtual, nem real. É um leitor específico, refinado, pois conhece todo o sistema de referências, intertextualidade e critérios de valor estético. Assim, a Estética da Recepção de Jauss (1994) marginaliza a grande parcela de leitores 'reais' ou 'empíricos', elegendo apenas o conjunto de leitores que compartilham o mesmo horizonte de expectativa, ou seja, referenciais e compreensôes similares.

Como interface às consideraçōes de Jauss (1994), Iser (1980) salienta que o trabalho literário ganha existência na convergência entre texto e leitor, a qual permanece no âmbito virtual, como em um lugar de encontro, entre o texto e o leitor, uma vez que náo se identifica com nenhum deles isoladamente. Ainda segundo Iser (1980), fazendo referências tanto à fenomenologia quanto à Gestalt, os diferentes leitores serão afetados de modos diversos pelo mesmo texto, fato que evidencia o nível no qual o texto literário transforma a leitura em um processo criativo, infinitamente superior à simples percepção do que está escrito.

Vale também reiterar a ideia de que a leitura é uma construção ininterrupta de ilusóes, apesar de náo afastar o leitor da realidade. Pelo contrário, o induz a conhecê-la, a questioná-la e a refletir sobre ela. A formaçáo de ilusôes durante a leitura permite que o mundo não-familiar do 
texto se torne conhecido aos poucos, através da construção de inferências, da criação de hipóteses e do estabelecimento de relaçôes (ISER, 1980).

Além disso, a memória e a percepção estão essencialmente envolvidas no processo de leitura. Isso explica as razóes pelas quais o leitor sente-se frequentemente envolvido em eventos narrados - que são reais apenas na mente do leitor. Ou seja, a mente humana não consegue mais distinguir o que foi vivido ou lido e essas memórias ficarão registradas no mesmo local. Assim, o leitor é encorajado a revelar-se a fim de experimentar uma realidade que não é a sua. É somente deixando para trás o conhecido que o leitor conseguirá se entregar à aventura que o texto literário lhe oferece. É o que comumente se entende por 'deixar-se levar pela história'.

A fim de expandir as possibilidades dessa perspectiva teórica, pretendese considerar como "leitor específico" ou "leitor ideal" o "leitor real", que se manifesta em espaços propícios para a discussão, apreciação e avaliação do texto em discussão (As Alegrias da Maternidade).

\section{Recepçáo: O que Comentam os Leitores}

Em início de janeiro de 2019, As Alegrias da Maternidade, de Buchi Emecheta, contava com 2.768 comentários no Aplicativo TAG Curadoria, na paleta Estante, na qual são listados todos os livros enviados aos assinantes, com suas informaçôes básicas: Avaliação dos Leitores, Título, Autor, Curador e Número de Páginas, além de uma foto da capa do livro.

Para a seleção dos comentários, dois foram os critérios utilizados: o primeiro, cronológico, privilegiando aqueles postados nos últimos 6 meses; e o segundo, de gênero, optando por analisar os comentários postados por mulheres leitoras. Como o número de comentários é relativamente grande, não há condições de analisar qualitativamente a todos em um único artigo. Desse modo, considerar apenas os comentários das leitoras ocorreu por algumas razóes, dentre elas, pela narrativa contemplar uma experiência tipicamente feminina - a maternidade; por ter sido escrito (Buchi Emecheta) e recomendado (Chimamanda Ngozi Adichie) por mulheres e; por fim, pelo fato de terem sido discutidas algumas das perspectivas envolvendo a Literatura Feminina durante a disciplina.

Foram excluídos dessa filtragem comentários que não apresentavam avaliaçáo da obra, ou seja, que mencionavam, por exemplo, o desejo de comprar o livro (em função de a assinante ter entrado no clube depois 
do envio desse título), ou ainda a intenção de fazer a leitura por não a ter realizado ainda. Assim, chegou-se ao número de 25 comentários a serem analisados à luz de teorias da Estética da Recepçáo e do Efeito Estético.

O fio condutor desse estudo intenta angariar argumentos que possam responder ao questionamento proposto ainda na introdução, além de tecer relaçôes com os aspectos teóricos que possam sustentar a análise. Ainda, a título de organização, os comentários estão enumerados por ordem cronológica e as iniciais das leitoras aparecem entre parênteses. Cada um dos comentários aparece em itálico e sem alteraçóes de sintaxe, ortografia ou acentuação ${ }^{12}$. Ao ler os depoimentos no aplicativo, ficam nítidas as impressóes gerais das leitoras, as quais, muitas vezes, são expressas através de adjetivos ou expressōes qualificadoras, emitindo um juízo sobre o livro. Alguns exemplos do registro de juízo da obra:

Comentário 01 (S.L.): Um livro lindo... emocionante e que nos faz refletir sobre a vida.

Comentário 3 (C.C.): Afinal, nasci sozinha e sozinha hei de morrer[...]. E assim foi. Livro sensacional. Obrigada, TAG, por trazê-lo!

Comentário 11 (A.T.): Amei, apesar da história ser pesada e triste, me fez refletir sobre o papel feminino na sociedade em geral.

Comentário 14 (A.B.): Eu adorei o livro! Comecei a ler assim que chegou... a estória incomoda e faz a gente refletir o que é ser mulher e mãe... acho que todo mundo deveria ler.

Comentário 18 (M.L.M.S.): Amei o livro! Vibrei com a personagem em suas conquistas e tragédias e me envolvi do início ao fim com a narrativa.

Comentário 24 (D.A.): É lindo demais!!! Ao retratar o tempo todo a condição vulnerável da mulher na sociedade, retrata também sua força sem tamanho... E tudo isso por meio de uma escrita envolvente e sensível.

Comentário 25 (S.B.F.): Que livro incrível! Que autora fascinante!! Me desprenderam lágrimas que não consegui conter... Não consigo expressar em palavras tudo que senti! A personagem Nnu Ego nos traz reflexôes tấo profundas e poderosas, tão feministas... Que jamais teria imaginado ler num

${ }^{12}$ Não foram feitas correções nos textos escritos pelas leitoras, mesmo que tenham apresentado algum tipo de incorreção. 
livro escrito na década de 70! Empoderador, incrível!

Ao final de qualquer leitura, é bastante corriqueiro que o leitor sintetize sua impressão de leitura através de um juízo de gosto, e os comentários apresentados confirmam essa constatação. É interessante considerar também como Jauss (1979) compreendia a questáo do juízo de gosto a partir de Kant (1959, p. 1959 apud JAUSS, 1979, p. 83), como segue: "o juízo de gosto não postula por si mesmo a adesão de cada um [...], ele apenas atribui a cada um esta adesão como um caso da regra, em vista do qual se espera a confirmaçáo, não a partir dos conceitos, mas pelo acordo dos outros” . O fato de os comentários estarem disponíveis no aplicativo para que todos os leitores da obra possam criticar reitera ainda mais a última parte da ideia de Kant (1959), pois é agradável ao leitor perceber que sua impressáo daquela obra encontra eco em outros leitores, consolidando sua primeira impressão.

Ainda, mesmo que de forma indireta, o juízo de gosto, no caso de As Alegrias da Maternidade, também ocorre através da menção à curadora da obra, Chimamanda N. Adichie. Ou seja, através do prestígio de quem indica, cria-se a expectativa de que o livro esteja à altura da indicaçáo. Por exemplo, nos comentários:

Comentário 19 (M.C.): Gostei demais da escritora, de sua biografia e do livro. Influenciada inicialmente pela indicação da Curadora Chimamanda, foi uma feliz opção de leitura. Despertou em mim um outro olhar e sentir pela maternidade. Muito bom.

Comentário 20 (V.M.P): Sou uma grande admiradora da curadora Chimamanda. Fiquei muito impressionada com o livro, com o choque cultural que ele explicita no desenrolar da história, entre a Nigéria tribal, a cultura das aldeias e a cultura da cidade, daqueles que se 'aculturam' em Lagos. O livro explora uma jornada da Heroína, contra os males do patriarcado. Muito atual, infelizmente. Muito forte! Final Brilhante!

Além do juízo de gosto, outros elementos vinculados à recepção da obra literária estão presentes nos comentários. Na sequência, percebe-se que algumas leitoras estabeleceram relaçóes com outras obras de modo a enriquecer sua experiência estética:

Comentário 02 (H.B.B): Saramago disse em Memorial do Convento, (mais ou menos assim) o lugar da maior alegria é o mesmo da maior dor. Confirma, portanto, o título "As alegrias da Maternidade" como a sombra, 
a ironia sugerida nas entrelinhas do romance e nos maravilhosos gráficos em relevo da capa. [...].

Comentário 23 (V.L.): Foi uma leitura impactante, gostei do estilo de escrita de Buchi. É forte e traz uma ancestralidade, algo de mágico mesmo. Ler literatura africana fez com que olhasse as coisas por outra perspectiva. Me fez pensar muito nas Epistemologias do Sul de Boaventura, que é esse olhar que é distinto da visão hegemônica e eurocêntrica. [...]

Como proposto anteriormente, diferentes leitores configurarão leituras distintas. Logo, torna-se plausível que algumas leitoras, considerando os comentários que relacionam obras, construam conexóes e relaçóes com ambientes já conhecidos por elas, reiterando o processo criativo da leitura como sendo algo infinitamente maior à mera decodificação (ISER, 1980). Em ambos os exemplos, a memória está claramente presente no processo de leitura, possibilitando que as leitoras partam de territórios conhecidos para estabelecer novas relaçóes com ambientes desconhecidos, permitindose descobrir a narrativa e constituir-se enquanto leitoras intertextuais.

Partindo da intertextualidade e pretendendo outras áreas do conhecimento, ampliam-se as construçóes de leitura cotejando as relaçóes sociais, históricas e culturais presentes na obra e registradas pelas leitoras:

Comentário 04 (C.O.): Já tinha uma expectativa bem alta para o livro e ele superou! Além de surpreender, aborda aspectos que sequer sabia que existiam, outras formas de sociedade nas quais nunca paramos para pensar. A autora tem um estilo que não cansa, não dá vontade de parar de ler.

Comentário 06 (T.C): [...] A obra reafirma o poder da cultura e raízes sobre o ser humano, como algo legítimo e bonito apesar de chocante aos olhos de quem sente e vive numa realidade distante daquela. As Alegrias da Maternidade é incisivo, transformador, educador e nos deixa a refletir do nosso início ao fim, principalmente nas últimas linhas... leitura essencial e encantadora.

Comentário 07 (E.S.P.): Narrativa transporta para outro tempo e lugar, história linda e muito bem contada, reflexóes sobre a cultura e os elos do matrimônio, a maternidade e o papel social da mulher. Acredito muito que cada obra dialoga diretamente com quem somos, e essa me falou ao coração.

Comentário 08 (F.N.): Primeiro pensamento: Muito bom não ser mulher na Nigéria. Segundo pensamento: Como podemos ser propriedade de um 
outro alguém? Uma supremacia infundada. E que mesmo no ocidente vemos tantos (homens e mulheres), mostrando apreço por um patriarcalismo desconexo e medíocre. Que possamos estar atentos; com os olhos bem abertos para não aceitar essa desigualdade que advém de uma humanidade cheia de desumanos. Afinal, ser mulher é muito mais que os estereótipos que se possam enxergar.

Comentário 10 (E.B.): O enredo é forte, leva a várias reflexôes quanto ao papel da mulher na(s) sociedade(s) e também nos faz refletir sobre o custo dos nossos sonhos.

Comentário 12 (A.R.C.S): Será que nós brasileiras estamos distantes da realidade das nigerianas?! O livro traz uma reflexão muito pertinente e confesso que vi muita semelhança entre tudo que vejo na nossa sociedade! Talvez lá as mulheres não disfarcem a submissão, aqui vejo as mulheres serem submissas e disfarçarem esta submissão, por vergonha!

Comentário 13 (T.M.): Literatura densa. É um livro forte que provoca reflexốes em vários temas: o papel do sentimento e a vocação de mãe, por meio de uma intensa trajetória da maternidade de Nnu Ego e seus 9 filhos; do papel da mulher, como mãe, esposa, filha, companheira, amante, trabalhadora e suas derivaçoóes de entrega, dedicação, submissão e idealização de felicidade. Por fim, outro tema abordado são as formas diretas e indiretas de escravatura, servidão e influência cultural local e colonizadora. Simplesmente incrível.

Comentário 17 (M.B.M.): Fantástico conhecer mais sobre a história e a literatura da Nigéria, da qual gosto muito, mas desconhecia a autora. O livro traz ótimas reflexóes sobre o papel da mulher na sociedade e, especialmente, como mãe, trazendo um título bem irônico. É uma história dolorida, muito boa, mas achei que a maioria dos comentários superestimam a obra. $\mathrm{Ou}$ talvez eu que tenha esperado demais...

Uma das constataçôes, a partir dos comentários, é sobre o papel das leitoras que se concretiza tanto no âmbito histórico quanto no individual, conforme as vivências e a compreensão anteriormente construídas durante e depois da leitura (ISER, 1996). O autor afirma também que a leitura ativa nossas faculdades, permitindo a recriaçáo do universo apresentado na obra literária. Assim, o produto desse processo criativo denomina-se "dimensão virtual do texto", segundo Iser (1996, p. 89 apud SILVA, 2003, p. 111), e essa dimensão virtual configura-se como o encontro do texto com a imaginação do receptor.

As constataçôes de Iser (1979) tornam-se pertinentes e plausíveis em 
relação aos comentários analisados, uma vez que as leitoras estabelecem ligaçôes entre a realidade em que elas vivem, as experiências que conhecem e a realidade e as experiências expostas na narrativa. Também se percebe um aprofundamento nas reflexóes, em termos sociais e culturais, e essas digressóes alimentam o questionamento em relaçáo ao universo vivido por essas leitoras, muitas vezes, imaginando-se na pele da personagem, vivenciando as pressóes culturais presentes na narrativa e cogitando possibilidades de rompimento com aquele contexto triste, ameaçador e cruel vivido pelas mulheres nigerianas à época.

Por fim, há também comentários que explicitam essa alteridade, relatando os sentimentos e as sensaçôes das leitoras enquanto se projetavam para dentro da narrativa, principalmente por se encontrarem em situaçóes similares ou por terem vivenciado sentimentos próximos aos da personagem:

Comentário 05 (B.C.Z): Livro que comecei a ler quando chegou o kit e eu estava com 37 semanas de gestaçáo, dei um tempo na minha vida e voltei a ler depois de oito meses e assim que li a última frase chorei muito. Livro sensacional, toca no coração.

Comentário 09 (E.X.): Tocante. Sensível. Chorei quando Nnu Ego morreu como se fosse uma irmá. Mulher resiliente e doce ao mesmo tempo.

Comentário 15 (M.G.W.): Assim que recebi esse livro peguei na hora a ironia do título! E quando terminei de ler, chorei, chorei. Sendo máe e ainda mãe solo, esse livro me tocou profundamente, no meu papel de mulher, mãe, trabalhadora e no quanto a sociedade romantiza a maternidade. E, nem há tanta diferença assim entre África e Brasil.

Comentário 16 (R.V.R.S.): Envolvente ao extremo! Ser mulher, mãe e esposa e ao mesmo tempo carregar a pecha de náo ser nada... Vi-me no lugar da personagem, buscando o motivo "dAs Alegrias da Maternidade" ... Inesquecível!

Comentário 21 (A.P.A.): O livro resume muito bem a dificuldade em nos adaptarmos às mudanças ocorridas ao longo da nossa vida. E como valores que eram tão sagrados vão sendo modificados e muitas vezes ficamos à deriva. Principalmente no papel de mãe e mulher! Um dos melhores livros que eu li!

Comentário 22 (T.P.): Um tapa na cara... dá vontade de falar que é injustiça e que Nnaife é um belo de um frouxo. Mas aí você lembra que o livro se passa em 1940 - 1950 ... e na Nigéria... Aí você pensa que tua vida tá 
ruim??? Podia estar pior. Amei!!

Ao observar que a Estética da Recepção permite perceber a troca de informaçóes entre texto e leitor, verifica-se uma dupla possibilidade de análise: a do texto, manifestando sua mensagem literária ao exterior; e a do leitor, relacionando suas experiências de mundo e de suas vivências. Nos comentários selecionados nesta parte, é clara a força do texto em adentrar na vida, nos pensamentos, nas reflexóes das leitoras, provocando-as ao ponto de registrar esse percurso estético no aplicativo do clube de leitura. Sabe-se que o texto tem esse poder em função do que cada uma delas elegeu como forma de explicitar as relaçóes construídas entre a obra literária e a obra vivida por cada leitora.

Já afirmava Jauss (1979, p. 69) que a primeira experiência que se tem de uma obra de arte ocorre na sintonia com o efeito estético "na compreensão fruidora e na fruição compreensiva”. Ou seja, no caso dos comentários das leitoras, nota-se que elas não apenas contemplam a obra literária, mas projetam-se para dentro dela e, ao vivenciar a obra esteticamente, distanciam-se de sua condição real, possibilitando que reflitam sobre suas próprias vidas, acolhendo suas escolhas ou as abandonando. Dessa forma, ocorre a experiência estética na qual, neste caso, as leitoras desfrutam do prazer suscitado pela apropriação subjetiva do texto. Em outras palavras, um texto literário só alcança significado através da experiência estética de leitura.

\section{Conclusáo}

Os clubes de leitura e todos os desdobramentos que eles têm lançado vêm criando novas perspectivas de leitura no Brasil. Para aqueles que compreendiam as mídias sociais e as tecnologias como formas de afastamento da leitura, têm-se argumentos contrários consistentes, uma vez que inúmeras plataformas são utilizadas como meios de divulgação, compartilhamento e discussão de leituras (vide perfis em redes sociais, plataformas de vídeos, aplicativos de leitura, para citar alguns). Assim, ler desperta interesse em uma parcela considerável da população brasileira. Talvez os clubes de leitura possam apontar caminhos para se chegar aos diferentes perfis de leitores, além de possibilitar o mapeamento dessas redes de leituras.

No intuito de sintetizar a análise proposta, percebe-se que é possível traçar algumas respostas para os questionamentos sobre o leitor, as leituras 
e suas relaçôes. Em primeiro lugar, pelos comentários selecionados, compreende-se alguns dos motivos pelos quais o texto As Alegrias da Maternidade foi táo bem avaliado pelos leitores da TAG Experiências Literárias. Percebe-se que as leitoras analisadas construíram vínculos fortes com a narrativa, projetando-se nela e repensando suas próprias condiçóes. Em segundo lugar, os comentários sugerem uma forte identificação com a condição de ser mulher, mãe, filha e, também, com a função social de submissão, preconceito e exclusão, sem esquecer da força, da resiliência e da paciência ilustradas na obra. Em terceiro lugar, a narrativa fez brotar lágrimas de algumas leitoras, conforme suas declaraçôes, fazendo com que o texto extrapolasse os limites lógicos, linguísticos ou estéticos, provocando sentimentos como empatia, pena, ira, desgosto, sofrimento, amor e alcançando níveis corporais de resposta à leitura. Em suma, um texto que imprime tal força em seus leitores assume seu protagonismo enquanto obra de arte e, certamente, será acolhido em tempos e espaços diferentes.

Conforme menciona Iser (1980), o impacto da realidade da obra depende da extensão dos pensamentos e das percepçóes dos leitores, no sentido de experimentar situaçôes diferentes de suas próprias. Quer dizer, somente abrindo mão de sua zona de conforto literária é que os leitores poderão participar da verdadeira aventura que cada texto oportuniza. Assim, aqueles que se permitem adentrar em um universo distante e novo estarão mais aptos a compreender textos de tal calibre.

Não obstante, problematizando a discussão sobre os leitores, Compagnon (2001, p. 153) deixa pendente alguns questionamentos: "como se encontram, se defrontam praticamente o leitor implícito e os leitores empíricos e históricos? Estes se curvam às instruçôes do texto? E, se náo se curvam, como detectar suas transgressóes?”. Ainda, como última reflexão, Compagnon (2001, p. 153) propóe: "a leitura real poderia constituir um objeto teórico"? Assim, o autor provoca o embate entre teoria e objeto teórico. Em outros termos, volta-se ao questionamento que impulsiona esta discussão desde seu título: é uma incoerência tentar aplicar elementos da Estética da Recepção e do Efeito Estético a leitores reais?

Os primeiros estudos nessa linha mostraram que é bastante controverso promover essa aplicaçáo. Entretanto, o que náo era possível a Iser (1979) e a Jauss (1979) à época era alcançar o 'leitor empírico', entendido aqui como o 'leitor real' e contemporâneo. Hoje, entretanto, através das tecnologias, esse impasse está eliminado.

Todavia, é necessário lembrar que ainda hoje não é simples estudar 
o leitor, uma vez que para tanto é necessário discorrer sobre psicologia, sociologia, história, entre outras disciplinas. Esse aspecto configura a maior dificuldade em pesquisar a relação texto-leitor, justamente por seu caráter interdisciplinar e processual: trata-se de um fenômeno vivo e em constante movimento, e "cobri-lo" com uma única perspectiva dá-nos sempre a sensação de estar usando um lençol que ora mostra a cabeça, ora os pés (RABINOWITZ, 1997).

Por sorte, o grande achado da Estética da Recepção e do Efeito Estético, ao focalizar a relaçáo texto-leitor, constitui na quebra de barreiras que separam o estudo da literatura de outras áreas, ampliando estudos e discussôes e promovendo a leitura a novos patamares.

\section{Referências}

BARTHES, R. A morte do autor. In: O rumor da língua. Tradução de Mário Laranjeira. São Paulo: Martins Fontes, 2004.

BOURDIEU, P. As regras da arte: gênese e estrutura do campo literário. São Paulo: Companhia das Letras, 1996.

CHARTIER, R. Práticas de leitura. São Paulo: Estação Liberdade, 1996.

COMPAGNON, A. O demônio da teoria: literatura e senso comum. Trad. Cleonice P.B. Mourão e Consuelo F. Santiago. Belo Horizonte: UFMG, 2001.

EMECHETA, Buchi. As alegrias da maternidade. Trad. Heloísa Jahn. Porto Alegre: Dublinense, 2017.

. In the ditch. Oxford: Heinemann, 1972.

. Second-class citizen. London: Allison \& Busby, 1974.

. The Bride Price. London: Allison \& Busby, 1976.

. The Slave Girl. London: Allison \& Busby, 1977.

. The Joys of Motherhood. London: Allison \& Busby, 1979.

ESCARPIT, R. Sociologia da leitura. Lisboa: Arcádia, 1969.

FISH, S. Is there a text in this class? The authority of interpretative communities. Cambridge: Harvard University Press, 1980.

GOETHE. J. W V. Fausto. Tradução, introdução e notas de João Barrento. Lisboa: Relógio D’Água. 2. ed., 2013.

GORDON, N. O físico. Rio de Janeiro: Rocco, 1986. 
ISER, W. Interação do texto com o leitor. In: JAUSS, Robert Hans et al (Org.). A literatura e o leitor. Coord. e Trad. Luiz Costa Lima. Rio de Janeiro: Paz e Terra, 1979.

ISER, W. The reading process: a phenomenological approach. In: TOMPKINS, J. (Org.) Reader-response criticism. Baltimore: The John Hopkins University Press, 1980.

ISER, W. O ato da leitura: uma teoria do efeito estético. Tradução Johannes Krestchmer. Sáo Paulo: Editora 34, 1999.

JAUSS, Hans Robert. A estética da recepção: colocações gerais. In: LIMA, Luiz Costa. (Org.) A Literatura e o leitor: textos de estéticas da recepção. Rio de Janeiro: Paz e Terra, 1979.

JAUSS, H.R. A história da literatura como provocaçáo à teoria literária. Tradução Sérgio Telarolli. São Paulo: Ática, 1994.

KANT, I. Crítica da Faculdade do Juízo. Rio de Janeiro: Forense Universitária, 1959.

RABINOWITZ, P.J. Reader-response theory and criticism. In: GRODEN, M.; DREISWIRTH, M. (Org.) Guide to literary theory and criticism. Baltimore: The John Hopkins University Press, 1997. Disponível em: http://www.press.jhu.edu/books/hopkins guide to literary theory/reader-response theory and criticism.html. Acesso em: 13 jan 2018.

SILVA, I. M. M. Interaçáo texto-leitor na escola: dialogando com os contos de Gilvan Lemos. 2003. 264 f. Tese (Doutorado em Letras), Programa de Pós-Graduação em Letras, UFPE, Recife, 2003. Disponível em: https://repositorio.ufpe.br/bitstream/123456789/7642/1/arquivo8144 1. pdf. Acesso em: 22 mar. 2021.

SLAUGHTER, K. A boa filha. Tradução Zé Oliboni. Rio de Janeiro: Harper Collins, 2018.

TAG EXPERIÊNCIAS LITERÁRIAS. Porto Alegre. Disponível em: https://site.taglivros.com/. Acesso em: 22 mar. 2021. 